\title{
SOSIALISASI TENTANG PEMANFAATAN APLIKASI ANDROID UNTUK MENDUKUNG PEMBELAJARAN SISWA SD NEGERI 66 SINGKAWANG TIMUR
}

\begin{abstract}
Dina Anika Marhayani ${ }^{1}$, Rika Wahyuni' ${ }^{2}$, Nurul Husna ${ }^{3}$
${ }^{1,2,3}$ STKIP Singkawang

Naram, Singkawang Utara, Kota Singkawang, Kalimantan Barat 791 dinaanika89@gmail.com, rikawahyuni142@gmail.com,nuna_husna@ymail.com

Abstract:This PPM activity is the socialization of the use of android applications to support learning of SD Negeri 66 Singkawang Timur in Sanggau Kulor Village. The PPM activity aims to provide teachers and students with insights about the use of android applications to make learning interesting. The PPM targets are 21 grade students of SD N 66 Singkawang Timur, and 6 teachers. The method of implementing PPM is divided into 3 stages, namely the planning, implementation and evaluation stages. The existence of PPM activities in the form of socialization about the use of android applications an increase in insight about android applications by 27 people, meaning that there was an increase of 100\%. The benefits that can be obtained by participants in this PPM activity include providing insight into the use of android for teachers and students.
\end{abstract}

Keywords: android, ppm, learning

\begin{abstract}
Abstrak:Kegiatan PPM ini yakni sosialisasi tentang pemanfaatan aplikasi android untuk mendukung pembelajaran siswa SD Negeri 66 Singkawang Timur di Kelurahan Sanggau Kulor. Kegiatan PPM memiliki tujuan untuk memberikan wawasan tentang pemanfaatan aplikasi android kepada guru dan siswa agar pembelajaran menarik.Target PPM iniyakni siswa kelas VI SD N 66 Singkawang Timur yang berjumlah 21 orang, serta guru yang berjumlah 6 orang. Metode pelaksanaan PPM dibagi menjadi 3 tahap yakni tahap perencanaan, implementasi, dan evaluasi.Adanya kegiatanPPM berupa sosialisasi tentang pemanfaatan aplikasi android terjadi peningkatan wawasan tentang aplikasi android sebanyak 27 orang, artinya terjadinya peningkatan 100\%.Manfaat yang dapat diperoleh peserta kegiatan PPM ini antara lain memberikan wawasan tentang pemanfaatan android bagi guru dan siswa.
\end{abstract}

Kata kunci: android, ppm, pembelajaran

$\mathrm{T}$ eknologi adalah alat yang diciptakan oleh manusia di zaman modern. Teknologi semakin meningkat cepat, beraneka ragamperalatan dibidang teknologi semakin kompleks (Sam'ani, 2018).Perkembanganperalatan di bidang teknologi yang semakin cepat tidak hanya digunakan dalam sektor perdagangan, kebijakan politik maupun perusahaan akan tetapi juga pada pembelajaran, seperti pengembangan, implementasi, serta evaluasi.

Teknologi juga sebagai media yang dapat dimanfaatkan sebagai transfer wawasan.Teknologi masukdalam beragam aspek pada aktivitas untuk mempermudah manusia dalam segala aktivitasnya.Pendidikan tidak terlepas dari pembauran teknologi untuk daya guna dalam pembelajaran.Pembauran teknologi pada aspek pendidikan harus dapat ditumbuh kembangkankan dengan baik demi tercapainya kehidupan yang arif dan cendekia yang 
tertuang dalam UUD 1945. Masyarakat yang arif dan cendikia berarti menfokuskan pada manusia yang bermutu.Manusia yang bermutuberpusat pada mutu pendidikan yang baik.Ensensi untuk menumbuhkan diri manusia memerlukan pendidikan agar dapat menjadi manusia yang bermutu dan bermanfaat bagi masyarakat, bangsa, dan negara.Pendidikan memperlukan teknologi karena teknologi sangat dibutuhkan dalam penyusunan media yang diperlukan dalam pembelajaran.Penggunaan media dapat meningkatkan keaktifan peserta didik (Yuntoto, 2015).Salah satu media untuk meningkatkan keaktifan peserta didik yakni media yang menggunakan aplikasi android.

Aplikasi android sebagai media yang bisa dipakai dalam memecahkan masalah pada dunia pendidikan.Hermawan (2011:2) Aplikasi Androidsebagai program yang dibuat untuk unit mobile berbasis Linux. Biraynara (2011:4) mengatakan Android adalah program untuk perangkat telepon seluler berbasis linux, Android menyediakan kebijakan bagi developer untuk membangun aplikasi milik mereka sendiri, sehingga dapat dijadikan penggerak. Android menurut Satyaputra dan Aritonang (2014: 2) adalah program untuk smartphone. Google Play dan iTunes sebagai program yang menyimpanberanekaragam jenis aplikasi bagi pemakai Android dan iOS untuk mendownload aplikasi yang diperlukan (Irsan, 2015). Ismanto (2017) mengemukakan bahwa Smartphone ialah telepon seluler yang dilengkapi dengan program aplikasi android.Program aplikasi android memiliki kegunaan pada masa globalisasi saat ini, karena dapat membawa manfaat pada proses belajar mengajar.

Program aplikasi android dapat memudahkan mentransfer pengetahuanpeserta didik dalam pembelajaran di kelas, khususnya pada peserta didik SD Negeri 66 Singkawang Timur.SD Negeri 66 Singkawang Timur berada di Sanggau Kulor.Sanggau Kulor merupakan kecamatan yang memiliki luas 16.626 Ha.Wilayahnya berupa bukit dan gunung seluas 18.496 hektar, Hal ini menjadikan sebagian penduduk yang berada di wilayah Singkawang Timur memanfaatkan tanah untuk perkebunan.Melihat kondisi secara fisik di SD N 66 Singkawang Timur yang berada di perbukitan dan gunung dan jauh dari kota, maka fasilitas yang ada di SD N 66 Singkawang pun masih terbatas.

Media yang digunakan oleh guru di SD N 66 Singkawang Timur masih terpaku pada papan tulis.Sedangkan dengan media papan tulispeserta didik kurang menyimakpelajaran, sehingga pembelajaran terkesan membosankan.Melihat permasalahan di atas media papan tulis kurang mendukung minatpeserta didik sehingga peserta didik menjadi pasif karena materi yang disampaikan guru tidak maksimal.Adanya program aplikasi android ini diharapkan dapat mempermudah guru dalam pembelajaran. Penyataan di atas didukung penelitian yang dilakukan oleh Labib dan Yolida (2019) menyebutkan bahwa karakteristik 
media pembelajaran berbasis android lebih mudah digunakan karena tidak memerlukan ruangan tertentu.

Berlatar belakang dari keadaan yang ada di SD Negeri 66 Singkawang Timur, bagaimana pelaksanaan sosialisasi tentang aplikasi androiddi SD Negeri 66 Singkawang Timur?Kegiatan PPM ini bertujuan untuk memberikan wawasan mengenai pemanfaatan aplikasi android kepada guru dan peserta didik agar pembelajaran menarik dan menyenangkan.

\section{METODE}

Peserta dalam kegiatan ini adalah peserta didikkelas VI SD N 66 Singkawang Timur sebanyak 21 orang dan guru sebanyak 6 orang.Metode pelaksanaan pengabdian dibagi 3 tahap, antara lain:

\section{Tahap perencanaan}

Tahap perencanaan menyiapkan sarana prasarana dan keperluan yang diperlukan dalam kegiatan pengabdian masyarakat.

\section{Tahap Implementasi}

Tahap ini yakni memberikan sosialisasi mengenai pemanfaatan aplikasi androiduntuk mendukung pembelajaran peserta didik SD Negeri 66 Singkawang Timur, dengan bentuk ppt nya yang menarik sehingga mau dibaca dan mudah dipahami oleh peserta didik dan guru SD N 66 Singkawang Timur. Selain itu, memberikan video mengenai aplikasi android, cara memilah aplikasi android yang sesuai dengan kebutuhan peserta didik, mengunduh dan menginstal aplikasi Android berbasis pendidikan, dan menerapakannya kepada peserta didik.Hal ini bertujuan untuk memberikan wawasan pada peserta didik dan guru dalam memanfaatkan aplikasi androidpada saat pembelajaran.

\section{Tahap evaluasi}

Tahap evaluasi yakni mengevaluasi seluruh kegiatan.Evaluasi dijadikan sebagai temuan tim jika menemukan masalah yang dapat dipakai sebagai evaluasi kegiatan PPM.Tingkat kesuksesaan dari kegiatan PPM ini dilaksanakandengan observasi langsung melalui penilaian kinerja dan kemahiran peserta dalam proses menguasai aplikasi android, cara memilah aplikasi android yang sesuai dengan kebutuhan peserta didik, mengunduh dan menginstal aplikasi Android berbasis pendidikan, dan menerapkannya kepada peserta didikdengan menyesuaikandengan indikator yang telah ada dalam rubrik. 


\section{HASIL PEMBAHASAN}

Permasalahan yang dihadapi dalam pembelajaran di SD N 66 Singkawang Timur sangat banyak.Media yang digunakan oleh guru di SD N 66 Singkawang Timur masih terpaku pada papan tulis. Sedangkan dengan media papan tulispeserta didik kurang menyimak pelajaran, sehingga pembelajaran terkesan membosankan. Media papan tulis kurang mendukung minat peserta didik sehingga peserta didik menjadi pasif karena materi yang disampaikan guru tidak maksimal.

Tahap dalam kegiatan PPM ini mencakup beberapa antara lain:

\section{Perencanaan}

Perencanaan merupakan sebagai langkah sebelum kegiatan program pengabdian masyarakat berlangsung. Tahap perencanaan antara lain komunikasi antar anggota PPM untuk merancang pelaksanaan secara sistematis dan terencana, pembagian kerja anggota PPM, serta menentukan jumlah peserta sosialisasi. Tahap perencanaan dilakukan perekrutan peserta, membuat instrumen program PPM, seperti lembar absen, lembar angket, lembar kerja, konsumsi, lokasi, dokumentasi, dan sebagainya.

2. Pelaksanaan

Kegiatan ini di hadiri oleh peserta didik kelas VI SD N 66 Singkawang Timur sebanyak 21 orang dan guru sebanyak 6 orang. Kegiatan ini dilakukan oleh 3 orang tim pengabdian dengan materi sebagai berikut:

a. Paparan secara umum tentang aplikasi android.

b. Jenis-jenis aplikasi edukasi android.

c. Cara memilahaplikasi edukasi android yang sesuai kebutuhan peserta didik.

d. Cara mengunduh dan menginstal aplikasi edukasi android.

e. Cara menerapkan aplikasi edukasi android kepada peserta didik.

Pada kegiatan PPM ini peserta hadir sebanyak 27 orang.Hal ini sesuai dengan sasaran yang direncanakan. Pada saat pelaksanaan kegiatan, telah disusun jadwal kegiatansosialisasi tentang pemanfaatan aplikasi androiduntuk mendukung pembelajaransiswa SD N 66 Singkawang Timur.Adapun susunan acaranya sebagai berikut: 
Tabel 1. Jadwal kegiatan sosialisasi tentang pemanfaatan aplikasi androiduntuk mendukung pembelajaran siswa SD N 66 Singkawang Timur

\begin{tabular}{ccc}
\hline No & Waktu & Kegiatan \\
\hline $\mathbf{1}$ & $08.30-08.40$ & Pembukaan \\
$\mathbf{2}$ & $08.40-09.00$ & Sambutan \\
$\mathbf{3}$ & $09.00-10.00$ & Materi \\
$\mathbf{4}$ & $10.00-10.15$ & Tanya Jawab/ sharing \\
$\mathbf{5}$ & $10.15-10.30$ & Istirahat + Konsumsi \\
$\mathbf{6}$ & $10.30-10.45$ & Evaluasi \\
$\mathbf{7}$ & $10.45-11.00$ & Penutupan dan Foto \\
& & Bersama \\
\hline
\end{tabular}

Kegiatan PPM diawai dengan tim menyampaikan materi dengan menggunakan PPT yang dilanjutkan sharing. Pada kegiatan inidiperoleh $89 \%$ guru dan peserta didikbanyak yang belum mengetahui aplikasi android. Hal ini dikarenakan peserta beranggapan bahwa aplikasi android hanya digunakan untuk mainan saja tanpa ada nilaipendidikan. Setelah adanya kegiatan PPM ini, Guru dan peserta didiktelah mengetahui bahwa terdapat aplikasi edukasi android yang dapat diterapkan sebagai media yang dapat digunakan dalam pembelajaran. Sejalan denganZulfadhilah dan Hidayah (2019) bahwa 95\% responden mudah memahami materi dengan adanya aplikasi android. Apilkasi android sangat penting di era perkembangan teknologi karena sebagai alat yang dapat membawa dampak bagi anak, baik positif dan negatif.Manfaat yang diperoleh dalam kegiatan ini adalah memberikan tambahan wawasan tentang bagaimana cara memanfaatkan aplikasi edukasi android dalam pembelajaran. Semoga dengan kegiatan ini dapat memberikan sumbangsih kepada masyarakat sebagai salah satu implementasi dari kegiatan PPM.

3. Tahap Evaluasi

Ketiga, kegiatan evaluasi dalam rangka mengikuti rangkaian kegiatan yang telah dilakukan sehingga tim pengabdian dapat menemukan masalah yang dapat digunakan sebagai bahan perbaikan dari kegiatan PPM. Hasil kegiatan PPM yang telah dilaksanakan menunjukkan peningkatan wawasan peserta yang berjumlah 27orang. Peningkatan terlihat adanya peningkatan wawasan sebelum dilaksanakan kegiatan PPM dan setelah dilaksanakan PPM yang dapat terlihat pada Gambar 1. 


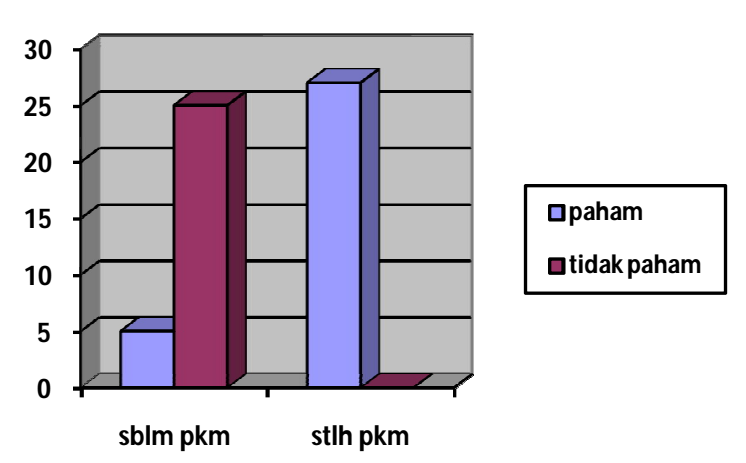

Gambar 1.Tingkat Pemahaman Aplikasi Android

Berdasarkan tabel diatas bahwa sebanyak 25 orang belum paham aplikasi android, hanya 5 orang yang sudah paham, setelah kegiatan pengabdian terjadi peningkatan wawasan tentang aplikasi android yakni sebanyak 27 orang, artinya terjadinya peningkatan 100\%. Adanya kegiatan sosialisasi ini membawa manfaat yakni dapat menningkatkan wawasan guru dan siswa tentang cara memanfaatkan aplikasi android dalam pembelajaran. Hal ini diharapkan agar pembelajaran lebih menarik.

\section{SIMPULAN}

Pelaksanaan kegiatan PPM ini berjalan dengan lancar, baik siswa ataupun guru pendamping ketika pelaksanaan terlihat antusias terhadap pemaparan tentang pemanfaatan aplikasi android dalam bidang pendidikan.Kegiatan Pengabdian Masyarakat ini bisa memberikan inovasi dalam bidang pembelajaran dengan aplikasi android.Namun, kendala yang dialami pada kegiatan ini adalah akses untuk menuju tempat pengabdian sangat jauh. Kegiatan pengabdian kepada masyarakat diharapkan para pengabdi akan bisa melakukan pendampingan untuk siswa sekolah tentang pembuatan media pembelajaran yang lainnya.

\section{UCAPAN TERIMA KASIH}

Ucapan terima kasih kami sampaikan kepada pihak-pihak yang telah berpartisipasi pada kegiatan pengabdian pada masyarakat ini, yaitu: STKIP Singkawang melalui Lembaga Penelitian dan Pengabdian Kepada Masyarakat (LP2M) yang telah mendanai program ini, Kepala Sekolah dan Guru serta para siswa kelas VISDN 66 Singkawang Timur, KelurahanSanggau Kulor yang telah bersedia menjadi peserta kegiatan ini hingga selesai. 


\section{DAFTAR PUSTAKA}

Biraynara. (2011). Pengenalan Dasar Android Programing.Diakses 15 Maret, 2014, darihttp://fahmindra-4.blogspot.n1/2013/09/pengenalan-dasar-androidprogramming.html.

Hermawan, S.S..(2011). Mudah Membuat Aplikasi Android. Yogyakarta: CV Andi Offset.

Irsan, M. (2015). Rancang Bangun Aplikasi Mobile Notifikasi Berbasis Android untuk Mendukung Kinerja di Instansi Pemerintahan. 1 (1).Retrieved fromhttp://jurnal.untan.ac.id.

Ismanto, E., dkk. (2017). Pemanfaatan Smartphone Android Sebagai Media Pembelajaran Bagi Guru Sma Negeri 2 Kota Pekanbaru. Jurnal Pengabdian UntukMu NegeRI, $1(1), 42$.

Labib \& Yolinda. (2019). Pengembangan Aplikasi berbasis Android yang Terintegrasi dengan Website sebagai Media Pembelajaran Biologi. Jurnal Bioterdidik, 7(5), 33-42.

Sam'ani. (2018). Rancang Bangun Aplikasi Pengawasan Dan PengendalianKomputer Laboratorium Multimedia STMIK Palangkaraya. Jurnal Sains Komputer dan Teknologi Informasi, 1(1), 33-38.

Satyaputra, A., dan Aritonang, E.M. (2014).Beginning Android Programming With ADT Bundle. Jakarta: Elex Media Komputindo.

Yuntoto, S. (2015).Pengembangan Aplikasi Android Sebagai Media Pembelajaran Kompetensi Pengoperasian Sistem Pengendali Elektronik Pada Siswa Kelas XI SMKN 2 Pengasih. Yogyakarta: Universitas Negeri Yogyakarta.

Zulfadhilah, M., dan Hidayah, N. (2019).Aplikasi Penyusunan Ikatan Kimia Berbasis Android Sebagai Media Pembelajaran.Jurnal Edik Informatika, 6 (1), 37-44. 